Article

\title{
Gentrification as an Emerging Source of Environmental Research
}

\author{
Juan Uribe-Toril * (D), José Luis Ruiz-Real and Jaime de Pablo Valenciano \\ Faculty of Economics and Business, University of Almería, Ctra. De Sacramento, s/n, 04120 Almería, Spain; \\ jlruizreal@ual.es (J.L.R.-R.); jdepablo@ual.es (J.d.P.V.) \\ * Correspondence: juribe@ual.es
}

Received: 23 November 2018; Accepted: 18 December 2018; Published: 19 December 2018

\begin{abstract}
Gentrification is a controversial term that refers to certain changes in neighbourhoods that result in the economic and social transformation of a low-income area into one of higher value, moving or pushing out the old population and businesses. The purpose of this paper is to highlight a new branch of research in the field of environmental studies. It presents a bibliometric analysis of the gentrification process, scanning the scientific articles published in journals since 1979, from different knowledge areas and analysing the impact factors and the evolution of the term itself. The review of scientific journals uses the Web of Science and Scopus databases for analysing the evolution of papers, the impact factors and references related to this concept. The results show that the literature related to gentrification is increasing at a very high rate, particularly in the fields of environmental science. Since 1987, the number of scientific papers in environmental studies that have focused on this topic have increased at an annual rate of $60.4 \%$, making it a promising subject for researchers. Thus, the article represents a contribution to identify the main trends in gentrification research and environment and, from there, propose future research initiatives.
\end{abstract}

Keywords: gentrification; environmental research; bibliometric analysis; WOS; Scopus

\section{Introduction}

This article addresses the process of gentrification as a mechanism of neighbourhood transformation [1-3] from the perspective of a bibliometric and literature review overview. It was initially used to describe the upgrading of old working-class housing in inner-city London [4]. The process of gentrification has become thoroughly global as an urban strategy that replaces liberal urban policy [5] and the inherently complex spatial phenomenon that embodies changing economic, demographic, social, physical, and cultural landscapes. Gentrification as a process has also expanded from contemporary global cities to encompass smaller villages [6].

Hwang [7] considers gentrification to be a process of neighbourhood selection-not only by relatively well-off individual households but also by developers, businesses, and institutions-that results in the physical, demographic, and cultural transformation of a low-income area into one of higher value, either a middle, or upper-class neighbourhood. The literature focuses mostly on cultural or sociological issues [8], small and medium-sized enterprises (SMEs) [9] or argues that gentrification processes can be defined using both economic and cultural explanations [10,11].

Different methodological frameworks obviously produce quite different accounts of gentrification [12] and there are so many perspectives on contemporary gentrification that what is now included as a part of the term itself has been stretched to the point where some have questioned its analytical use [13]. However, discussions about the gentrification phenomenon and specifically the growing interest in the environmental science discipline justify the need for the current study. 
The literature about the gentrification process includes different, and sometimes diffuse, definitions of the concept. The term was first used by Ruth Glass [14] after observing changes in the social structure and housing markets of inner London where the working class areas were being displaced by the middle class.

Discussion about the definitions and concepts is timely and important because gentrification studies are currently facing a period of intensive reorientation, [15] and academic literature has been searching for the core of the definition. Some authors focus on the development of the industrial structure of cities [16-18]. A notable feature of the literature on gentrification considers social and cultural patterns and the background of changes in the shape of neighbourhoods $[7,19,20]$. According to some authors, gender and gentrification have a close relationship [12,21-23]. Finally, other researchers have argued that gentrification is a capital movement, highlighting economic, commercial and business transformation of neighbourhoods and cities [24-26].

Several approaches have been applied to these studies, which have produced contradictory results as to whether or not gentrification should be supported or controlled. Obviously, the process can impact neighbourhoods in a positive or negative manner. On the one hand, urban gentrification can be a vital tool and creates challenges by shifting market forces, establishing new enterprises and increasing sales for businesses [3,27]. On the other hand, other authors focus on the undesirable consequences of gentrification for racial and low-income minorities living in neighbourhoods such as unemployment or rent increases $[7,28,29]$.

The difficulties in establishing a homogenous definition, a theoretical approach or a proper framework of research are balanced with the empirical perspective of the extensive bibliography available. Gentrification has been used as a case study in many cities. As previously stated, London was the first example of gentrification [14,16,30-34]. Soon, however, this urban process was identified in other cities with a significant industrial heritage: New York [18,30,35-38], Newcastle [39,40], Berlin [41,42], Milan [43,44] or Barcelona [45,46]. Since then, however, gentrification has expanded to become a global phenomenon and scholars shave analysed changes in neighbourhoods and cities around the world including Vancouver [47], Montreal [48], Chicago [49], Sydney [50] or Beijing [51,52].

The purpose of this research is to understand, from a bibliometric perspective of scientific literature, the current state of research on the subject of gentrification in the knowledge area of environmental studies and the evolution of publications, authors or countries in which these investigations are framed. A bibliometric analysis facilitates the evaluation of developments in knowledge on a specific subject and assesses the scientific influence of research and sources. Thus, this article represents a contribution to identify the main trends and, from there, propose future research initiatives.

This paper examines the literature about this field of research, identifying 2175 research studies in peer-review journals retrieved from the Thomson Reuters' Web of Science (WOS) database Core Collection from 1979 to 2017. A further 1951 articles were retrieved from the Scopus database. The list was then filtered down to 547 (WOS) and 440 (Scopus) publications that mentioned gentrification in the field of environmental studies. The evolution and impact of the term was also subsequently analysed. The studies began in 1979, when the first article was detected in the Scopus database.

The paper is organized as follows. Section one presents an introduction to the theme and a literature review on gentrification theories. Section two presents a brief overview of bibliometric methods and results. Finally, the last section includes some final remarks which provide suggestions for further research.

\section{Methodology}

In order to study the gentrification phenomenon and its growing influence in environmental publications, a bibliometric analysis was used. Garfield [53] first described a citation index for science. The publication of indexes in the WOS online database core collection and Scopus database were selected for this study. Both are multidisciplinary databases which mainly record scientific articles, reviews, and books, but also other documents such as editorials, letters, books, reviews, etc. There is 
a close correlation between several bibliometric indicators and databases [54] and WOS and Scopus were considered to be the best options due to their quality and that they were the most commonly used databases and the largest repositories of data referring to citations and summaries of peer reviewed research literature. VOSviewer, a freely available computer program for constructing and viewing bibliometric maps [55], was used to construct and display a co-citation and keyword map for environmental scientific journals.

This methodology has been successfully used in recent research [56,57] and generates useful information for researchers evaluating scientific activity. Two previous bibliometric articles about gentrification and bibliometric studies were found on WOS [58,59], neither of which focus on environmental science. This methodology should provide several staggered results. It should provide a concise and precise description of the experimental results, their interpretation as well as the experimental conclusions that can be drawn. This bibliometric analysis comprises five steps (Figure 1):

(1) A definition of the search criteria, keywords and time periods. (2) Selection of a database. (3) Adjustment of research criteria, selection, compilation of the categories of bibliographic information and filtering for articles in the environmental field. (4) Export of final data. (5) Analysis of the information.

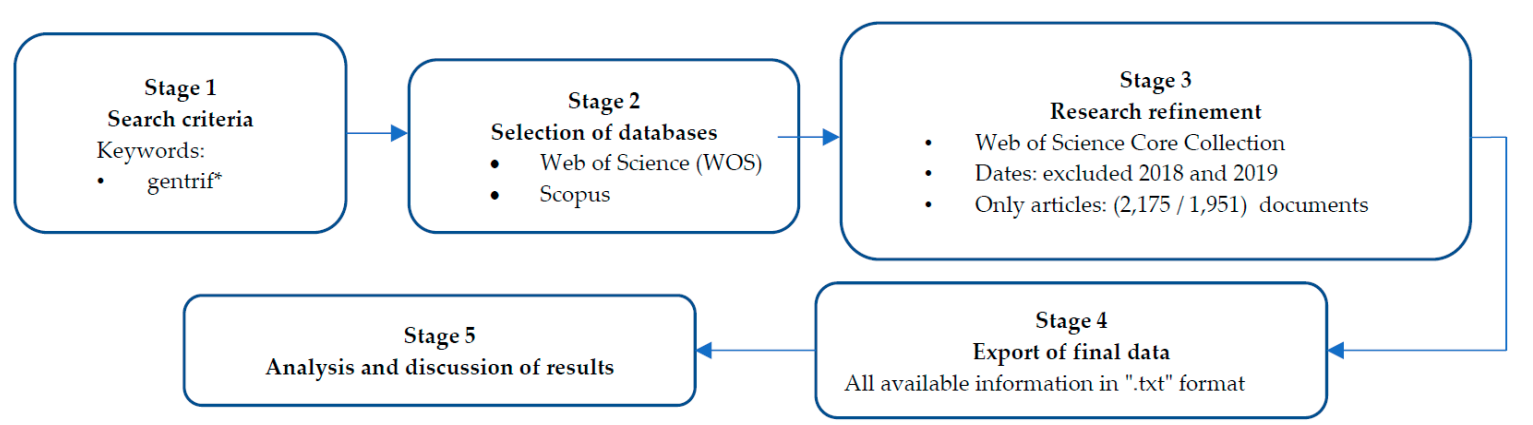

Figure 1. Five stages of the bibliometric analysis.

\section{Discussion and Results}

Gentrification is a very particular term and none of its synonyms fully encompass the concept. Therefore, the keyword search focused on the word gentrify and its derivatives (gentrification, gentrify, gentrifier, etc.). The preliminary results of this search, encompassing the period of 1979 up to the time of this study and without applying any filters, was a total of 3275 documents according to WOS, and 2897 according to Scopus.

In the adjustment of research criteria, the WOS Core Collection was defined and filtered, redefining the date, excluding 2018 and 2019, and filtered to only include articles. This first selection resulted in 2175 articles on WOS and 1951 for Scopus, which were then used to develop the first stage of the study.

The standing of a journal, in terms of quality and prestige, is a multidimensional concept in which several factors can intervene, such as citation, time, language, etc. [54]. In this paper, various variables, usually analysed for measuring bibliometric studies and summarizing the results, were encoded: the impact of papers indicated by the number of references received from other subsequent publications (number of citations); the impact factor of journals in the Journal Citation Report@ (JCR-Quartiles) and the Scimago Journal Country Rank (SJR-Quartiles), as well as the Hirsch index (h-index and averages). Hirsch [60], in 2005, proposed that index $h$, defined as the number of papers with citation number $\geq h$, as a useful index to characterize the scientific output of a researcher.

\subsection{Language and Most Influential Countries}

The ranking of the most influential countries (Table 1) is headed by the USA, with more than a third of the total contributions-34.06\% (WOS), 32.08\% (Scopus). This is followed by the United Kingdom with 420 and 326 articles on WOS and Scopus, respectively. This is not a coincidence as these countries were where gentrification first began (Figure 2). Also, this topic has been profoundly 
studied in Canada, the third-ranked country, in well-known gentrification areas such as Montreal and Vancouver $[47,48]$. The results for Australia and the Netherlands produced about 100 articles each. It was decided that individual data below $1 \%$ could be considered as irrelevant.

Also the number of citations per country follows a similar proportion. The first quartile of countries in the ranking encompasses $86 \%$ of the total citations (Figure 3). The map projection from Microsoft Excel software used the Mercator projection and doesn't show the real size of the countries.

Table 1. Ranking of countries with the highest number of articles and citations.

\begin{tabular}{cccccccccc}
\hline & \multicolumn{9}{c}{ WOS } \\
\hline Countries & W/S & A & TC & AC & h-Index & A & TC & AC & h-Index \\
\hline USA & $1 / 1$ & 741 & 12,658 & 17.08 & 47 & 626 & 14,850 & 23.72 & 52 \\
UK & $2 / 2$ & 420 & 10,392 & 24.74 & 57 & 326 & 11,091 & 34.02 & 59 \\
CANADA & $3 / 3$ & 198 & 3552 & 17.94 & 30 & 160 & 4239 & 26.49 & 33 \\
AUSTRALIA & $4 / 4$ & 117 & 2124 & 18.15 & 22 & 89 & 2037 & 22.89 & 22 \\
NETHERLANDS & $5 / 5$ & 112 & 1447 & 12.92 & 20 & 75 & 1281 & 17.08 & 20 \\
GERMANY & $6 / 6$ & 89 & 735 & 8.26 & 13 & 64 & 646 & 10.09 & 13 \\
SPAIN & $7 / 8$ & 71 & 422 & 5.94 & 12 & 55 & 659 & 11.98 & 14 \\
CHINA & $8 / 12$ & 61 & 446 & 7.31 & 12 & 27 & 336 & 12.44 & 11 \\
FRANCE & $9 / 7$ & 42 & 332 & 7.90 & 10 & 63 & 460 & 7.30 & 13 \\
SWEDEN & $10 / 15$ & 41 & 342 & 8.34 & 10 & 20 & 363 & 18.15 & 11 \\
CHILE & $11 / 9$ & 39 & 232 & 5.95 & 8 & 32 & 333 & 10.41 & 11 \\
TURKEY & $12 / 10$ & 38 & 216 & 5.68 & 10 & 29 & 223 & 7.69 & 8 \\
BELGIUM & $13 / 14$ & 30 & 370 & 12.33 & 11 & 25 & 329 & 13.16 & 9 \\
POLAND & $14 / 16$ & 20 & 133 & 6.65 & 6 & 19 & 218 & 11.47 & 6 \\
PORTUGAL & $15 / 17$ & 20 & 69 & 3.45 & 3 & 19 & 110 & 5.79 & 5 \\
\hline
\end{tabular}

W/S: Ranking on Web of Science (WOS) and Scopus databases; A: the annual number of articles; TC: the annual number of citations in total articles; AC: annual number of citations by article; h-index: Hirsch index.

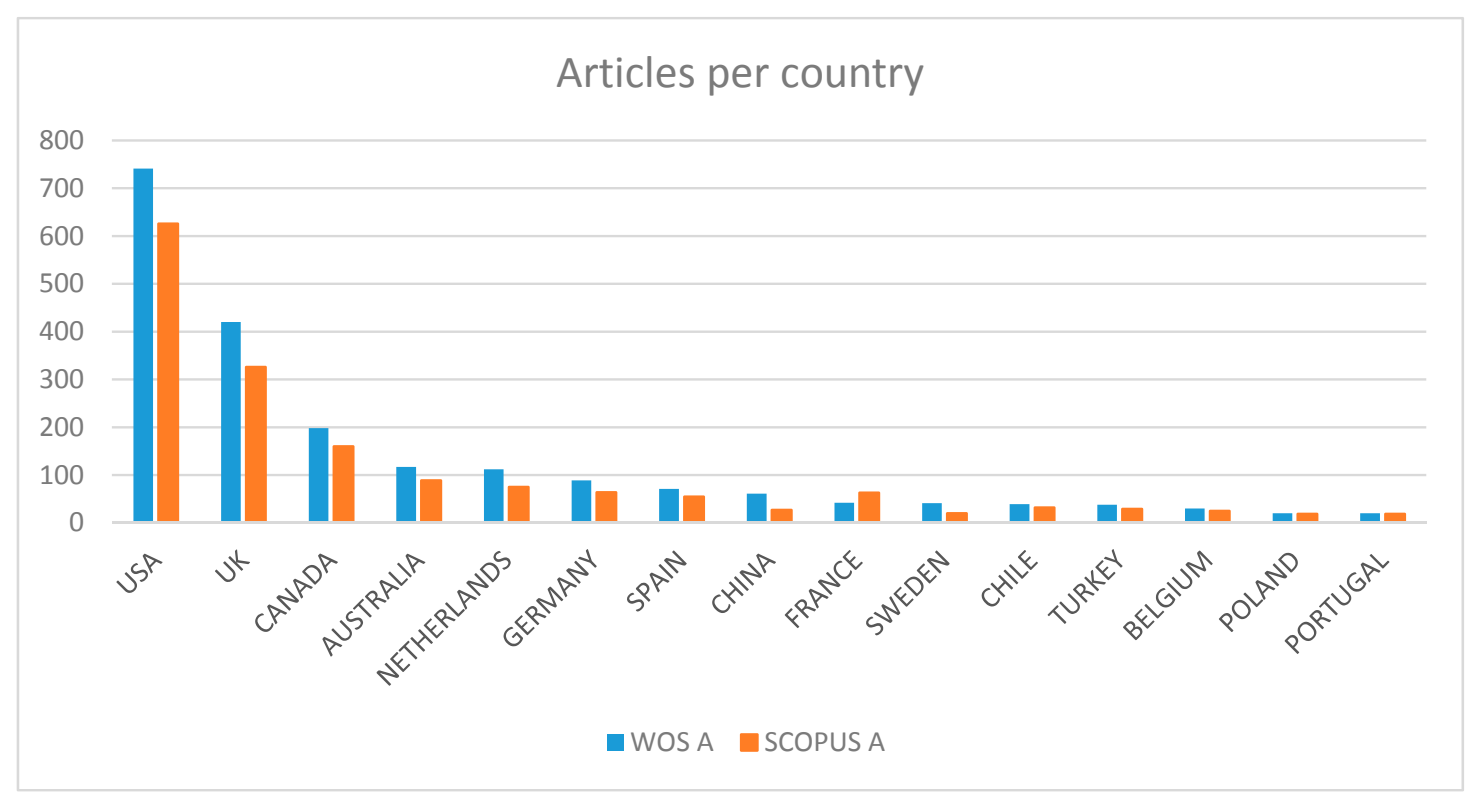

Figure 2. Number of articles per country. 


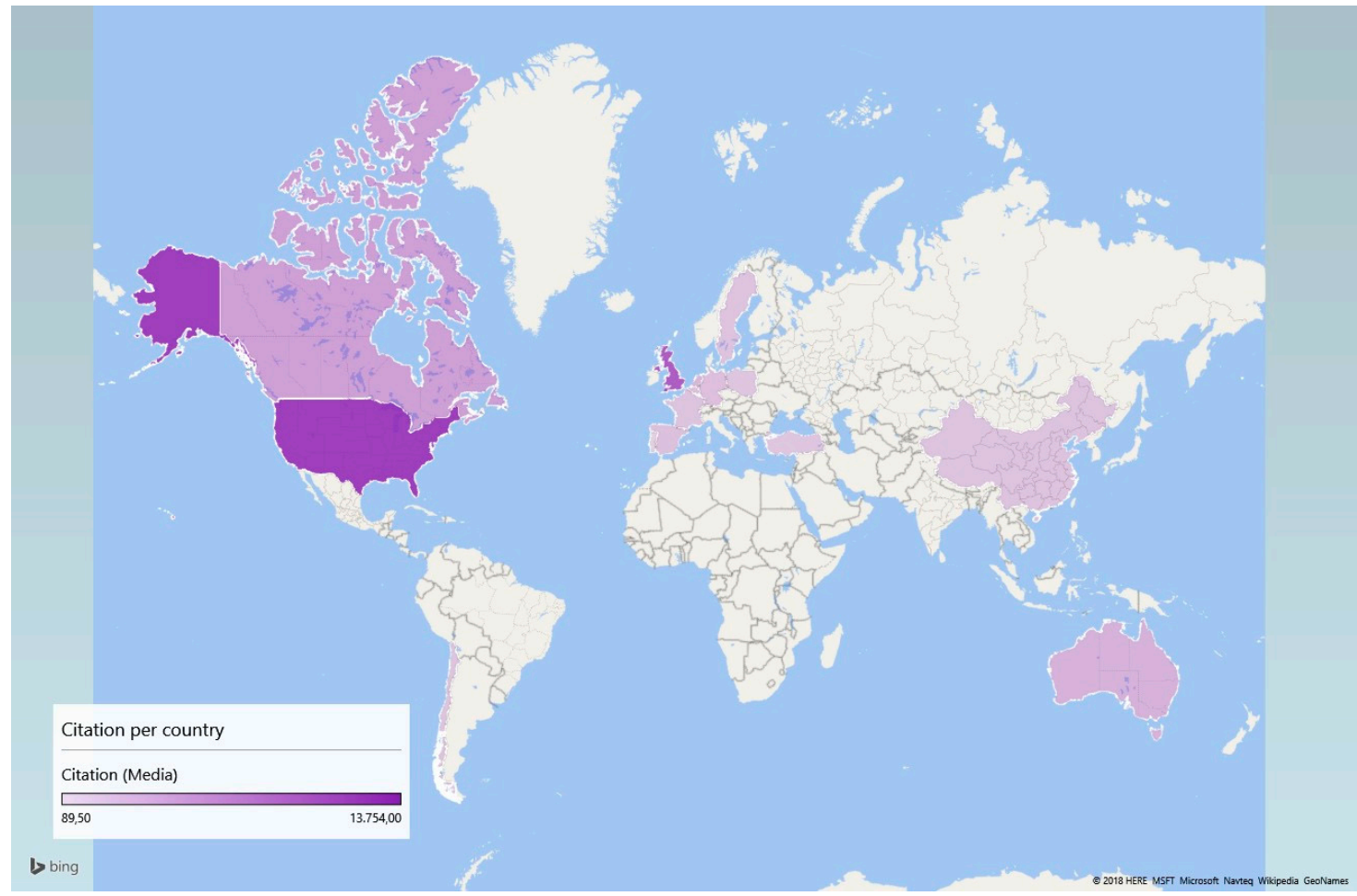

Figure 3. Map of citations per country.

As expected, the most common language of publication is English (Table 2), and in this case there is a link between the countries and language in terms of percentages. Taking into account that English-speaking countries yield more than three quarters of the articles published, English is the dominant language and only Spanish, German, Portuguese and French have a relevant $(<1 \%)$ position.

Table 2. Languages used in research articles about gentrification.

\begin{tabular}{cccccccccc}
\hline & \multicolumn{3}{c}{ WOS } & \multicolumn{7}{c}{ SCOPUS } \\
\hline Languages & W/S & A & TC & AC & h-Index & A & TC & AC & h-Index \\
\hline ENGLISH & $1 / 1$ & 2006 & 32,671 & 16.29 & 75 & 1736 & 39,179 & 22.57 & 86 \\
SPANISH & $2 / 3$ & 97 & 154 & 1.59 & 5 & 72 & 308 & 4.28 & 9 \\
GERMAN & $3 / 4$ & 22 & 59 & 2.68 & 4 & 39 & 128 & 3.28 & 6 \\
FRENCH & $4 / 2$ & 21 & 43 & 2.05 & 2 & 79 & 229 & 2.90 & 9 \\
PORTUGUESE & $5 / 5$ & 12 & 3 & 0.25 & 1 & 23 & 40 & 1.74 & 4 \\
\hline
\end{tabular}

W/S: Ranking on WOS and Scopus databases; A: the annual number of articles; TC: the annual number of citations in total articles; AC: annual number of citations by article; h-index: Hirsch index.

\subsection{Number of Publications per Year}

Although the term gentrification has appeared since the mid-60s [14], the first journal that refers to this topic was published in 1979, in Chicago, in the Journal of the American Planning Association [5]. This article was classified in the areas of social sciences (urban studies, geography, planning and development), public administration, international trade and foreign investment and economics.

From 1979 to 2002, there was only an average of less than 20 articles per year that used the term. The following decade shows a slight increase but the 21st century brought exponential growth of $60.4 \%$ in the number of articles (Figure 4) from 2006 to 2010. This notwithstanding, 2013 shows a break in the constant rise which is line with the general decline in the number of research articles published that year in other fields. 
The relevance of the term in current studies is evident. The average annual growth rate of articles, in the period 1979 to 2017 is $21.27 \%$. Both databases showed that there have been as many articles published in the first semester of 2018 as there were between 1979 and 2002.

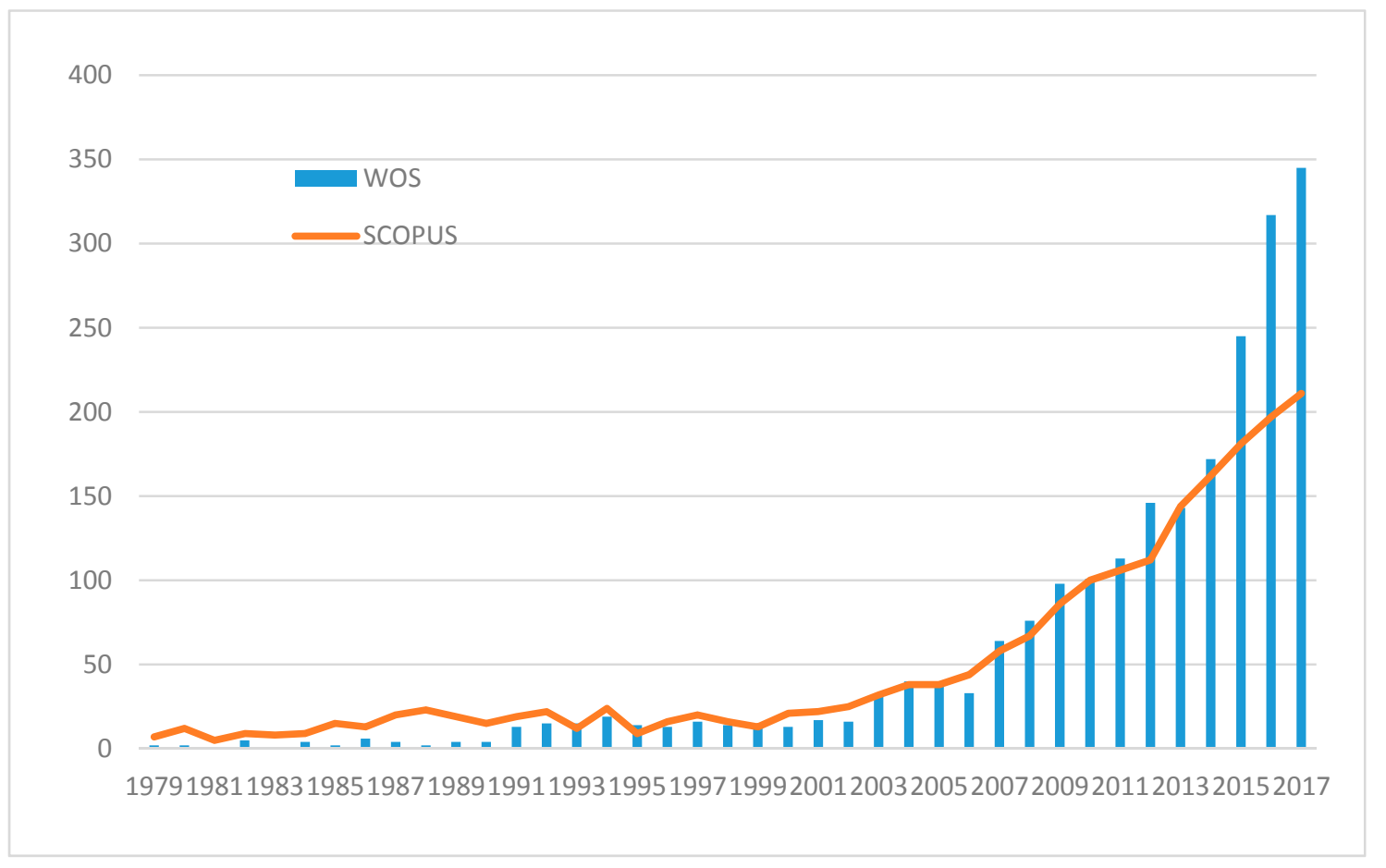

Figure 4. Number of publications per year.

\subsection{Most Influential Journals}

The number of journals on the WOS database that have published articles related to gentrification is 270 , while on Scopus there are 160. This suggests that the topic has been adopted in a wide range of journals in different knowledge areas. Table 3 shows the most significant journals with articles about gentrification.

Table 3. Journal and impact.

\begin{tabular}{cccccccccc}
\hline & \multicolumn{3}{c}{ WOS } & \multicolumn{3}{c}{ SCOPUS } \\
\hline Journal & W/S & A & TC & AC & h-i & A & TC & AC & h-i \\
\hline $\begin{array}{c}\text { URBAN STUDIES } \\
\text { INTERNATIONAL JOURNAL OF }\end{array}$ & $1 / 1$ & 193 & 5698 & 29.52 & 40 & 132 & 5756 & 43.61 & 41 \\
URBAN AND REGIONAL & $2 / 2$ & 99 & 3171 & 32.03 & 26 & 70 & 3851 & 55.01 & 26 \\
RESEARCH & & & & & & & & & \\
URBAN GEOGRAPHY & $3 / 3$ & 91 & 1236 & 13.58 & 20 & 66 & 1278 & 19.36 & 21 \\
ENVIRONMENT AND & $4 / 4$ & 86 & 2243 & 26.08 & 27 & 54 & 2278 & 42.19 & 29 \\
PLANNING A & $5 / 5$ & 59 & 747 & 12.66 & 14 & 37 & 629 & 17.00 & 14 \\
CITIES & $6 / 10$ & 38 & 510 & 13.42 & 12 & 24 & 616 & 25.67 & 15 \\
HOUSING STUDIES & $7 / 9$ & 36 & 1381 & 38.36 & 17 & 26 & 1579 & 60.73 & 15 \\
ANTIPODE & $8 / 6$ & 35 & 466 & 13.31 & 11 & 33 & 599 & 18.15 & 13 \\
JOURNAL OF URBAN AFFAIRS & $9 / 12$ & 30 & 405 & 13.50 & 10 & 23 & 385 & 16.74 & 9 \\
CITY COMMUNITY & $10 / 8$ & 30 & 988 & 32.93 & 18 & 29 & 1103 & 38.03 & 17 \\
URBAN AFFAIRS REVIEW & $11 / 11$ & 27 & 519 & 19.22 & 13 & 23 & 456 & 19.83 & 13 \\
GEOFORUM & $12 / 13$ & 27 & 710 & 26.30 & 14 & 18 & 668 & 37.11 & 11 \\
JOURNAL OF RURAL STUDIES & 12.11 \\
\hline
\end{tabular}

W/S: Ranking on WOS and Scopus databases; A: the annual number of articles; TC: the annual number of citations in total articles; AC: annual number of citations by article; h-i: Hirsch index. 
If the items with less than a $1 \%$ of representation are ignored, then a total of 12 journals can be ranked with the leading journal being Urban Studies, which seems to have studied this subject in greater depth and has the highest h-index. The journal has published 193 articles and its first publication on gentrification dated back to 1995. The International Journal of Urban and Regional Research was ranked second, with more than 3000 citations and a 26 h-index. Ranked third was Urban Geography, with an average of 13.58 citations per article on WOS and 19.36 on Scopus. As mentioned, the journal with the oldest article, published in 1979, was the Journal of the American Planning Association.

It is noteworthy that the journal Antipode, with only 36 articles on WOS and 26 on Scopus and an h-index of 17 on WOS and 15 on Scopus has such a large number of references 1381 and 1579 respectively. The reason for this is the article "New globalism, new urbanism: Gentrification as global urban strategy" (Smith, 2002), which was cited more than 700 times in the WOS Core Collection and 1000 times on Scopus.

\subsection{Most Eminent Authors and Cited References in Influential Journals}

This study identifies 2820 authors who published between one and 19 articles. $84.5 \%$ of the authors have published one paper and a further $9.3 \%$ have published two. Analysis of the articles with regard to authorship reveals that the top 10 most active scholars have produced $5.8 \%$ of the papers.

Table 4 shows the most prolific authors in terms of gentrification. The author who had the most articles published was Loreta Lees, from King's College of London, with a total of 19 papers. This author accumulated 1331 (WOS) and 2056 (Scopus) citations and has an H-index of 14 and first published in this field in 1994. The second most prolific author for both databases was Tim Butler from the University of East London. This author had a total of 960 citations (WOS) and 1110 on Scopus with an H-index of 13. Chris Hamnett, from King's College London, was the third most prolific author with an average of 41.20 citations per article (WOS) and 59.33 (Scopus).

All the bibliometric indicators are based on the idea that the impact of a paper can be measured by counting the number of other papers which make reference to or cite it. This study differentiates between paper and author citations. According to the data, the most influential paper is by Peck [61] in his free access article, cited 934 times. However, Professor Neil Smith could be said to be the most influential author, not only for his 14 articles (Scopus) about gentrification which have been cited 2074 times but also for the six articles with his surname in the title, refuting or supporting his theories.

Table 4. Top 10 authors.

\begin{tabular}{cccccccccc}
\hline & \multicolumn{3}{c}{ WOS } & \multicolumn{5}{c}{ SCOPUS } \\
\hline Author & W/S & A & TC & AC & h-i & A & TC & AC & h-i \\
\hline LEES, L. & $1 / 1$ & 19 & 1331 & 70.05 & 14 & 19 & 2056 & 108.21 & 15 \\
BUTLER, T. & $2 / 2$ & 18 & 956 & 53.11 & 13 & 15 & 1101 & 73.40 & 13 \\
HAMNETT, C. & $3 / 3$ & 15 & 618 & 41.20 & 11 & 15 & 890 & 59.33 & 13 \\
BOTERMAN, WR. & $4 / 14$ & 13 & 148 & 11.38 & 8 & 8 & 131 & 16.38 & 7 \\
SMITH, D. & $5 / 11$ & 14 & 485 & 34.64 & 11 & 9 & 436 & 48.44 & 7 \\
LEY, D. & $6 / 5$ & 12 & 895 & 74.58 & 9 & 12 & 1185 & 98.75 & 10 \\
BRIDGE, G. & $7 / 7$ & 12 & 426 & 35.50 & 10 & 12 & 546 & 45.50 & 9 \\
SMITH, N. & $8 / 4$ & 11 & 1845 & 167.73 & 10 & 14 & 2690 & 192.14 & 11 \\
MUSTERD, S. & $9 / 22$ & 11 & 70 & 6.36 & 11 & 5 & 64 & 12.80 & 3 \\
SLATER, T. & $10 / 6$ & 10 & 608 & 60.80 & 10 & 12 & 945 & 78.75 & 10 \\
ZUKIN, S. & $23 / 8$ & 7 & 456 & 65.14 & 5 & 11 & 751 & 68.27 & 9 \\
ATKINSON, R. & $15 / 9$ & 8 & 366 & 45.75 & 7 & 10 & 615 & 61.50 & 7 \\
VAN CRIEKINGEN, M. & $24 / 10$ & 6 & 123 & 20.50 & 4 & 10 & 164 & 16.40 & 5 \\
\hline
\end{tabular}

R W/S: Ranking on WOS and Scopus databases; A: the annual number of articles; TC: the annual number of citations in total articles; AC: annual number of citations by article; h-i: Hirsch index.

\subsection{Areas of Knowledge: Environmental Research Literature}

The second filter applied analysed was whether gentrification is becoming an emerging source for environmental research. The previous list of articles was sifted and only papers in the environmental 
field were selected. Since the notion of environmental research is a transversal term that could involve different concepts, our results are based on the WOS and Scopus classifications of research areas.

The new list of 547 works from WOS and 440 papers from Scopus represents more than $25 \%$ of the total number of articles (Figure 5), and the increase shows changes in this area of knowledge from 1979 , the date of the first study about gentrification in the environmental field.

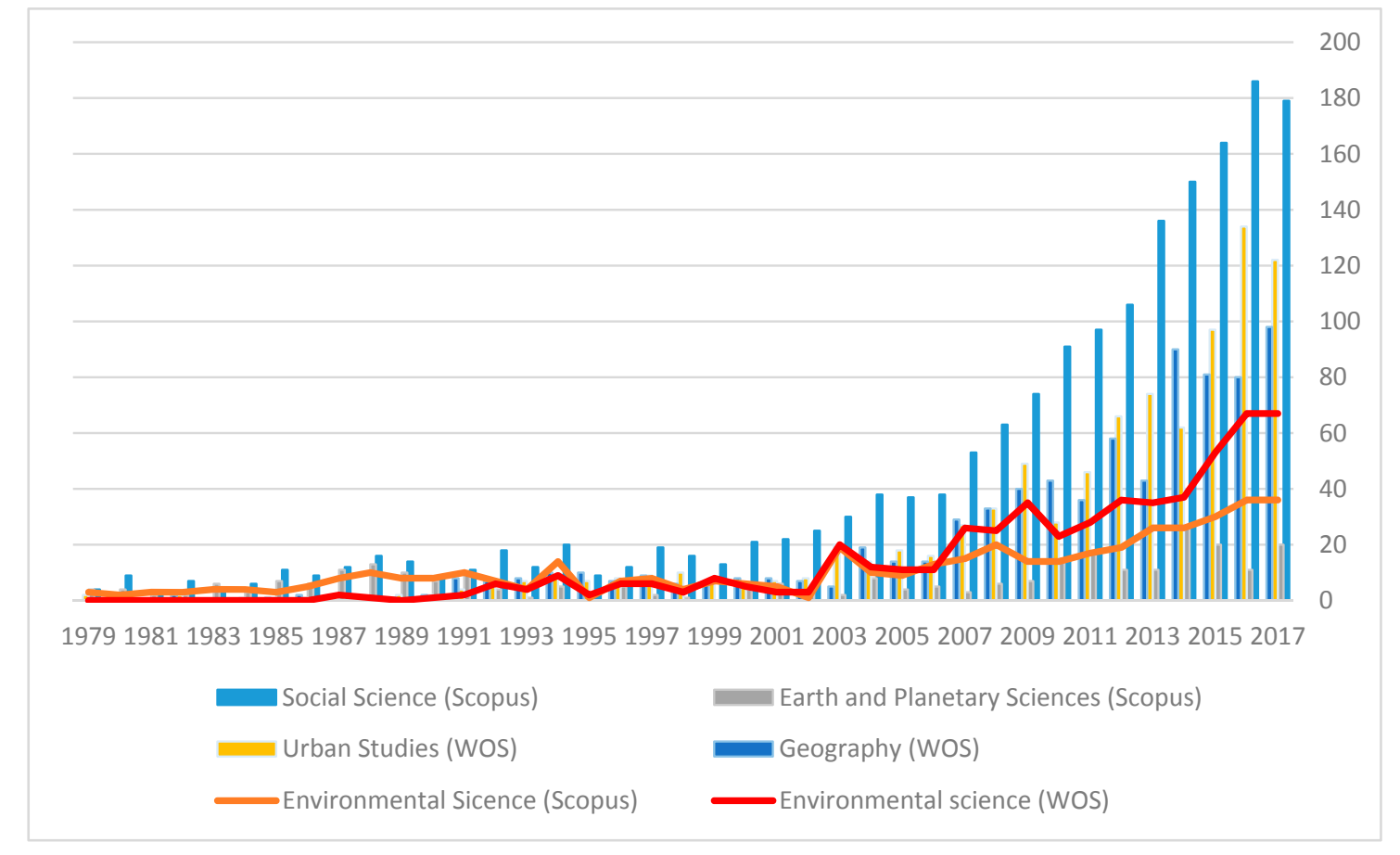

Figure 5. Research areas.

Once more, just in the general keyword search, there was a very wide variety of journals dealing with this topic in the environmental field of research. According to WOS and Scopus, Butler, Hammnett, Boterman and Lees were the most influential authors in this specific area. With regards to the field of environmental studies, the term gentrification and its derivatives appeared in 113 different journals. The United States, United Kingdom and Canada were once again the countries with the greatest number of articles and citations.

The papers from the selected list of environmental articles were analysed one by one and each article was compared to the Journal Citation Index (JCR) and the Scimago Journal and Country Ranking (SJR) for the year it was published.

Figures 6 and 7 show the evolution of gentrification articles in the environmental field and also the progression in the number of papers published in Q1 and Q2 journals in the last 10 years. From 2008 to 2017, there have been 209 articles about gentrification in environmental science published in Q1 JCR (Figure 6).

The inclusion of the factor "no impact" is also considered as often times the journal did not include the article in the JCR or SJR in the same year of publication. It was also decided not to include articles published in 2018 as the JCR and SJR impact factor for that year would not be available until 2019.

The average annual growth rate of articles on gentrification in the environmental field is $47.22 \%$ in the period between 1982 and 2017. This is 15.8 points higher than for the total of all knowledge areas.

The number of citations presents a similar tendency: 2574 references, although in this instance, the time lapse between the article's publication and the dates of the citations must be taken into account (Figure 7). As long as the papers are less than 5 years old, in the last five years from 2013 to 2017 the citation rate decreases in a normal way, but publications from 2007 to 2013 show the highest peak. 


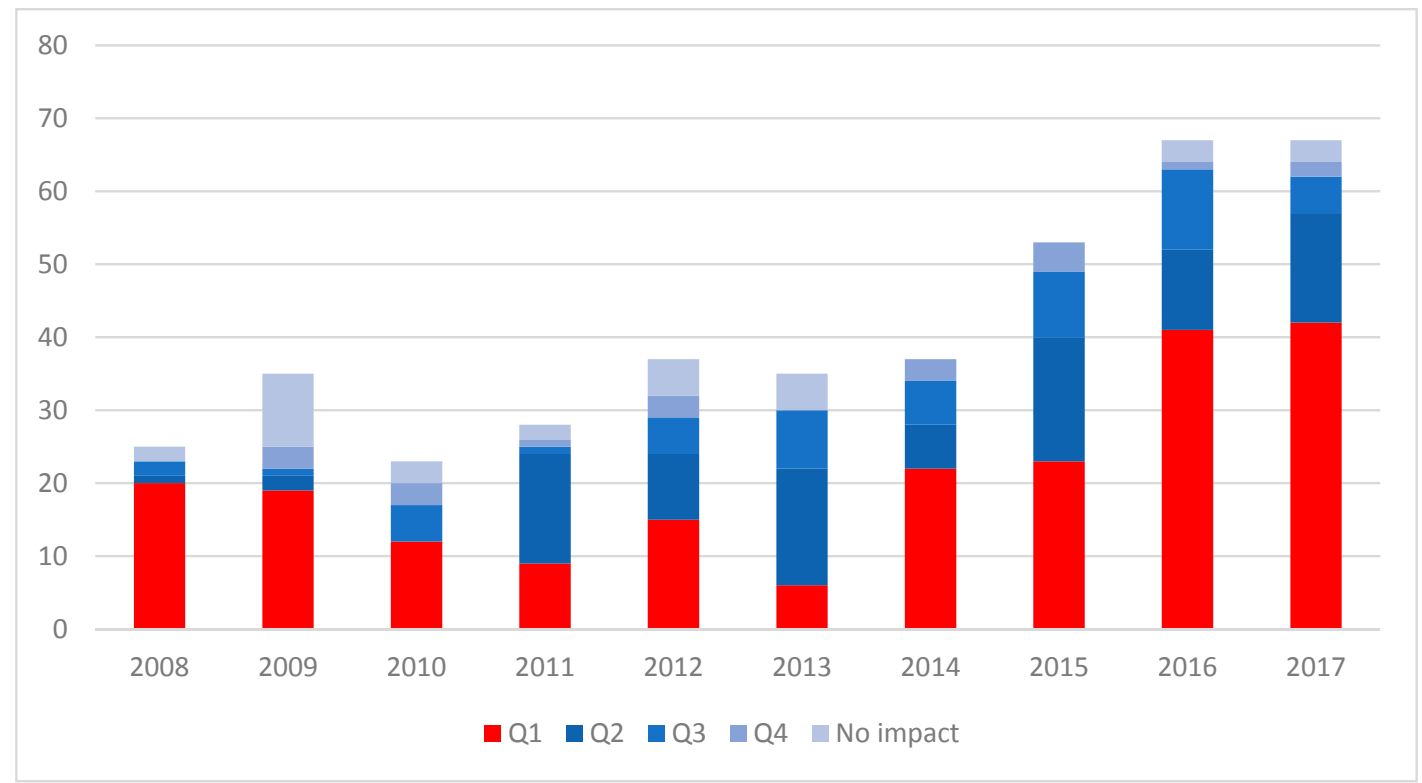

Figure 6. Journal impact factors (WOS).

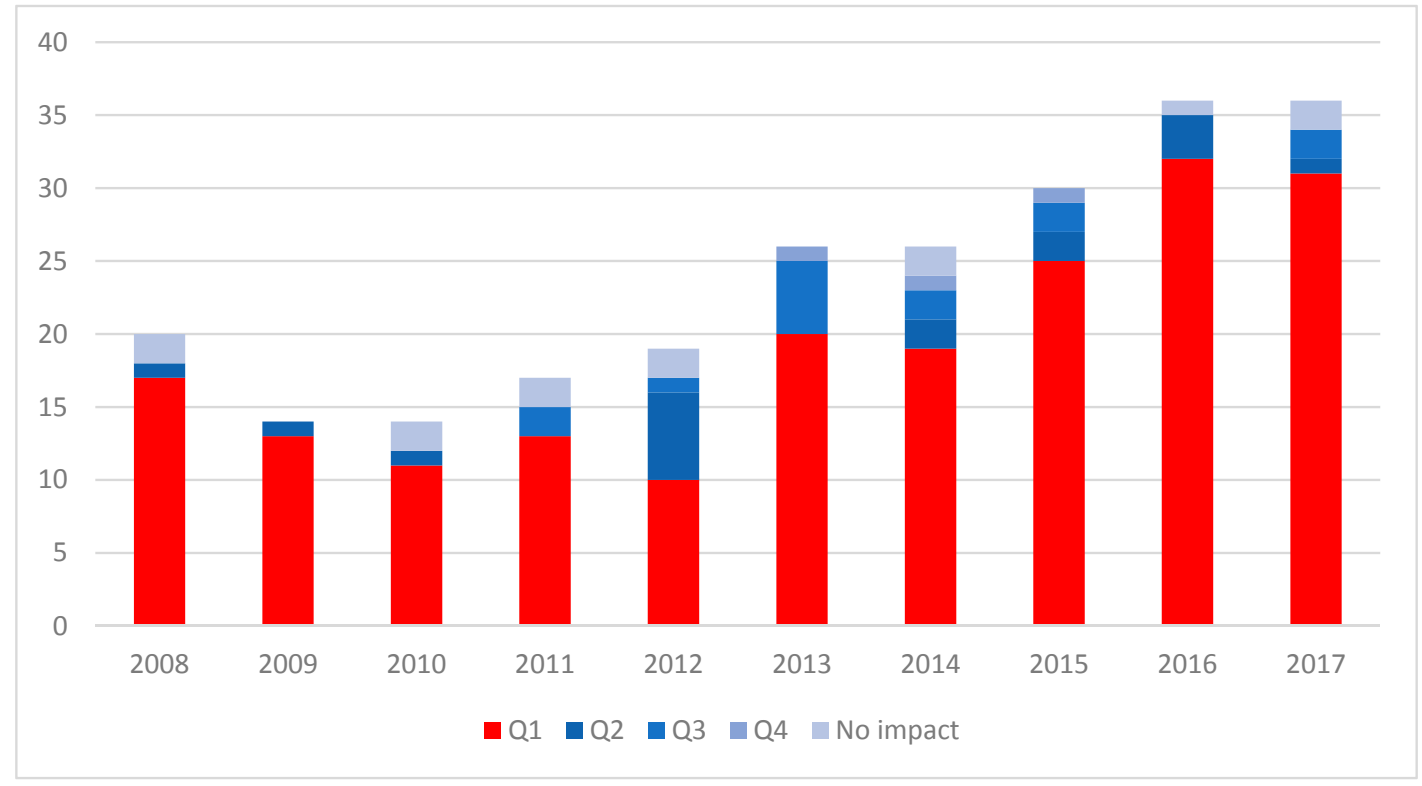

Figure 7. Journal impact factors (Scopus).

Figures 8 and 9 show maps of the network based on the co-occurrence of the principal keywords on WOS and Scopus.

In order to analyse the evolution of the most frequent terms used by the authors in their research on gentrification in environmental science, a trend map is created, using a fractional counting method and based on the bibliographic data on co-occurrence of the keywords used by the authors in the WOS database (Figure 8). This map is based on the average number of publications per year and uses different colours to highlight the keywords most used by authors in each of the last 10 years. The most recent keywords are marked in yellow, so the most important trends may be identified. Nowadays, research on gentrification is focused on topics such as green space, environmental justice, redevelopment, or sustainability. The other important emergent subject in gentrification is residential mobility and urbanism. Other emergent topics regarding gentrification are neoliberalism, geographies and transition. Shanghai appears in recent studies underscoring China as an emerging location of interest. 
Figure 9 shows a map based on Scopus data on co-occurrence on the all the keywords using a full counting method. A minimum of 10 occurrences of a keyword was established for the 1858 keywords founded. The keywords with the greatest total link strength have been selected. This map is useful for showing trends in research about gentrification in the field of environmental science and shows the main interactions between the most frequent terms in this research, and the existing clusters, highlighting the term "gentrification" as a central theme. In the network analysis, the keywords build clusters and the size of the circle is determined by the weight of the item. Thus, the higher the weight of an item, the larger the circle. Lines between items represent links, and the distance between two keywords indicates the relationship of the keyword with the co-occurrence links.

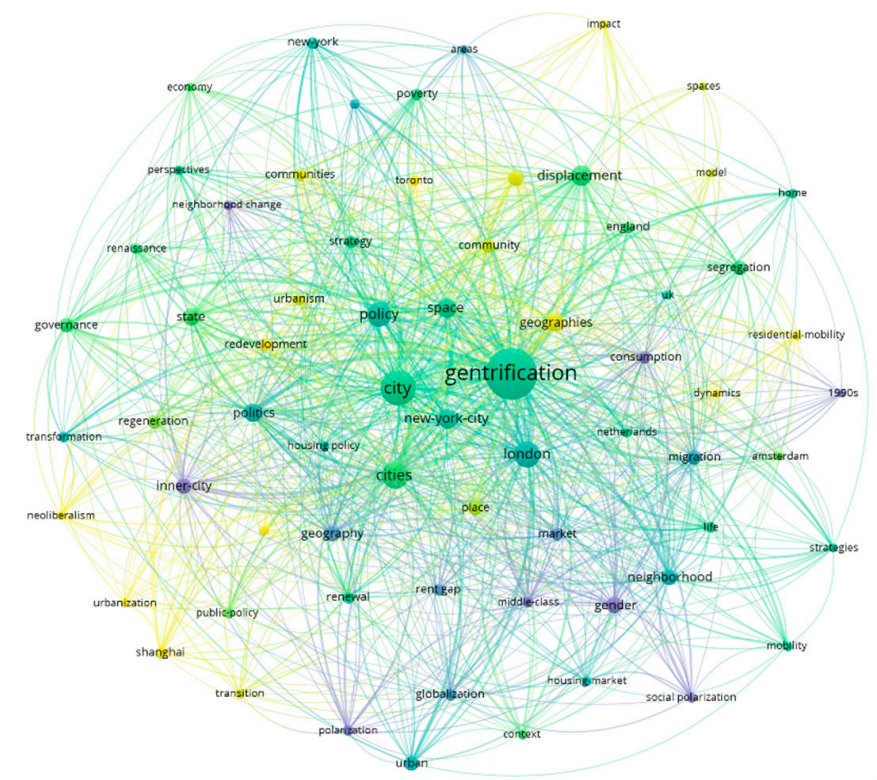

S nosviewer

Figure 8. Network of keywords co-occurrence in gentrification on environmental science on the WOS database.

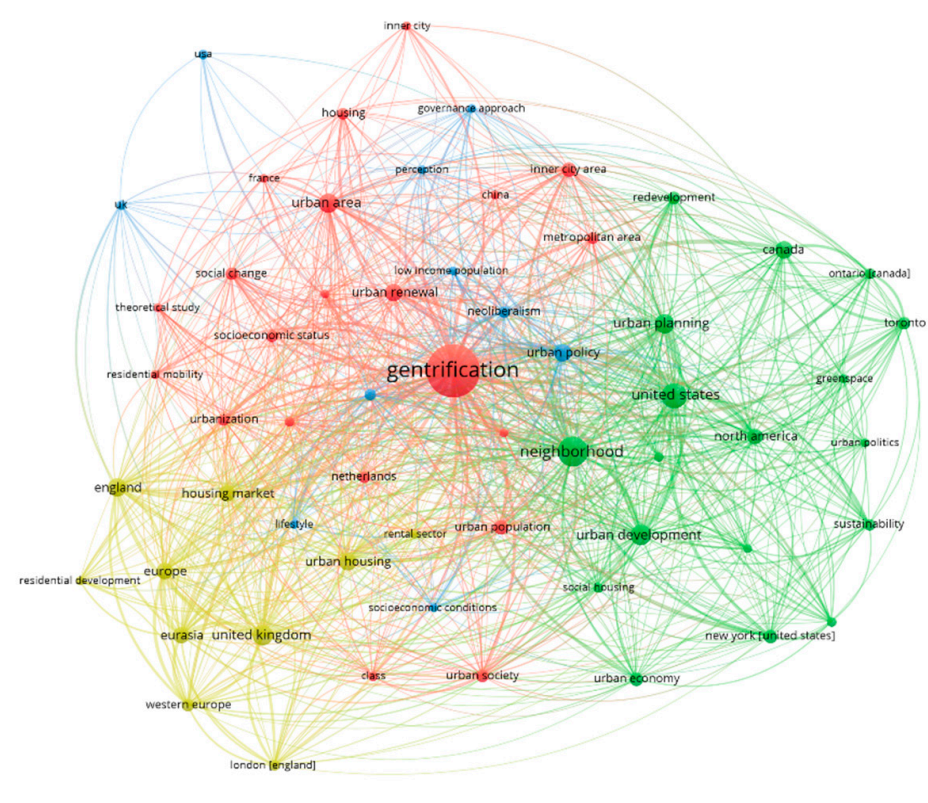

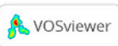

Figure 9. Network of keywords co-occurrence in gentrification on environmental science on the Scopus database. 
Therefore, four clusters are identified:

Cluster 1 (red): the red lines represent the term "neighbourhood" in terms of the number of repetitions. This cluster also includes the following terms: gentrification, housing, housing policy, inner city, inner city area, metropolitan area, class, residential location, residential mobility, social change, socioeconomic status, theoretical study, urban population, urban renewal, urban society and urbanization. The group also includes locations such as China, France, Germany and the Netherlands.

Cluster 2 (green): the green lines represent a cluster represented by the terms affordable housing, greenspace, neighbourhood, redevelopment, social housing, sustainability, sustainable development, urban development, urban economy, urban planning and urban politics. We can observe that in this group, only North American terms are included: New York, North America, Ontario, Toronto and the United States. This cluster is mainly focused on sustainability and highlights the relationship of these terms with the American continent.

Cluster 3 (blue): the blue cluster consists of 10 items: displacement, governance approach, lifestyle, low income population, neoliberalism, perception, socioeconomic condition and urban. On the left side of the figure, with small circles and weak links with other keywords, we found the USA and UK. The position of terms on the map shows that these keywords are transversal concepts entangled with other clusters.

Cluster 4 (yellow): the last cluster, in yellow, is made up of 10 items, including: housing market, rental sector, residential development and urban housing. There are several related locations but all of them are in Europe: England, Eurasia, Europe, London, United Kingdom or Western Europe. There are no terms related with the environment in this cluster and the items are related to the market and the economy (note: although there are studies about gentrification on the Australian continent [50], a gap in research is found in Africa and South America and it could be interesting to address this gap with further research in the future).

\section{Conclusions}

The main contribution of this paper consists in showing the evolution of gentrification research on environmental issues (number of articles and quality in terms of citations and JCR-SJR impact), the discrepancies between the most productive and most influential authors and trends for future research.

The interest in bibliometric studies lies in their implication in decision making, as a part of knowledge management, by suggesting the development of lines of research not previously studied or supervising the development of other research fields. Also, it assesses the scientific work of authors, institutions and even countries. In this case, the term gentrification has been analysed.

There is no single definition of gentrification, and the literature continues to discuss both its positive and negative effects. Gentrification is a process that results in the physical, economic, demographic, and cultural transformation of neighbourhoods.

This study uses a double-filter of data for the bibliometric analysis. From the preliminary result of 3275 possible works on the WOS database and 2898 works on the Scopus database related with the topic, 2175 (WOS) and 1951 (Scopus) were scientific articles. Of these, 547 (WOS) and 440 (Scopus) corresponded to the environmental science knowledge area. Most of the articles were in English. Furthermore, there is a strong relationship between the publication averages of the top four countries, which are all English-speaking.

Based on this, the analysis draws on the most common bibliometric indicators used by journals and researchers, namely citations, h-index, averages, clusters and JCR-Quartiles and SJR-Quartiles. Countries, languages, journals, authors and knowledge areas have also been evaluated. In this study, the research was focused on articles related to environmental impact.

The study identified discrepancies between the most influential author, the most influential paper and the most prolific author: Smith, Peck and Lees respectively. The number of different journals (270) 
in different areas that have published articles about gentrification is quite surprising and reflects how mainstream this concept has become.

The analysis has shown that research on gentrification in the environmental field is a growing phenomenon, especially in the last 10 years. The importance of this area of research is such that gentrification can be considered, for the most part, a social and economic process with environmental consequences. Nowadays the literature is focused on items such as green space, environmental justice, redevelopment, or sustainability. Cluster analysis of keywords also shows differences in studies and locations, linking European studies with the market or the economy while American studies focus more on sustainability.

Therefore, authors are encouraged to study the gentrification process from an environmental point of view, thus proving that it is an emerging interdisciplinary area of research.

With regards to the limitations of this research, although the WOS and Scopus databases are probably the most influential tools for building a bibliometric analysis, there are others such as Google Scholar or Latindex, which could be considered in the future. This research is focused on articles published in scientific journals; for future research, it would be also interesting to include other types of documents, such as books or conference papers. Although the results would be the same, the methodology of this paper could be expanded to include other quantitative or qualitative tools, adding knowledge maps or visuals. A 'non-solution' limit is the best way to measure the impact of a journal. Literature continues searching for new methods, and future studies could perhaps focus on innovative solutions.

For future research on the bibliometric analysis of this term, it could be interesting to delve into different fields of this discipline, for more specific research on some of the subjects related to these topics. Future studies could also focus on studying gentrification theory or building a compendium by using a meta-analysis.

Author Contributions: The research was designed and performed by J.U.-T. and J.L.R.-R. The data was collected by J.U.-T. and J.L.R.-R. Analysis of data was performed by J.L.R.-R., J.d.P.V. and J.U.-T. Finally, the paper was written by J.U.-T. and J.L.R.-R. All the authors read and approved the final manuscript.

Funding: This research received no external funding.

Conflicts of Interest: The authors declare no conflict of interest.

\section{References}

1. Smith, N. New globalism, new urbanism: Gentrification as global urban strategy. Antipode 2002, 34, 427-450. [CrossRef]

2. Brown-Saracino, J. A Neighborhood That Never Changes: Gentrification, Social Preservation, and the Search for Authenticity; The University of Chicago Press: Chicago, IL, USA, 2009.

3. Elmedni, B.; Christian, N.; Stone, C. Business improvement distristricts (BIDs): An economic development policy or a tool for gentrification. Cog. Bus. Manag. 2018, 5, 1-19. [CrossRef]

4. Doucet, B. A process of change and changing process: Introduction to the special issue on contemporary gentrification. Tijdschr. Econ. Soc. Geogr. 2013, 105, 125-139. [CrossRef]

5. Smith, N. Toward a theory of gentrification-Back to the city movement by capital, not people. J. Am. Plan. Assoc. 1979, 45, 538-548. [CrossRef]

6. Nelson, P.B. Spatial and temporal scale in comparative approaches to rural gentrification. Dialogues Hum. Geogr. 2018, 8, 40-46. [CrossRef]

7. Hwang, J. Pioneers of Gentrification: Transformation in Global Neighborhoods in Urban America in the Late Twentieth Century. Demography 2016, 53, 189-213. [CrossRef] [PubMed]

8. Smith, N. Of yuppies and housing: Gentrification, social restructuring, and the urban dream. Environ. Plan. D 1987, 5, 151-172. [CrossRef]

9. Parker, J.N. Negotiating the Space between Avant-Garde and "Hip Enough": Businesses and Commercial Gentrification in Wicker Park. City Community 2018, 17, 438-460. [CrossRef]

10. Lloyd, R. Neo-Bohemia: Art and Commerce in the Postindustrial City; Routledge: London, UK, 2005. 
11. Deener, A. Venice: A Contested Bohemia in Los Angeles; University of Chicago Press: Chicago, IL, USA; London, UK, 2012.

12. Lees, L. A reappraisal of gentrification: Towards a 'geography of gentrification'. Progr. Hum. Geog. 2000, 24, 389-408. [CrossRef]

13. Boddy, M. Designer Neighborhoods: New-building residential development in Nonmetropolitan UK cities-The case of Bristol. Environ. Plan. A 2007, 39, 86-105. [CrossRef]

14. Glass, R.L. Aspect of Change in The Gentrification Debates: A Reader; Centre for Urban Studies, MacGibbon \& Kee: London, UK, 1964.

15. Bernt, M. Gentrification between urban and rural. Dialogues in Human Geography 2018, 8, 31-35. [CrossRef]

16. Hamnett, C. Gentrification and the middle-class remaking of inner London, 1961-2001. Urban Stud. 2003, 40, 2401-2426. [CrossRef]

17. Lester, T.W.; Hartley, D.A. The long-term employment impacts of gentrification in the 1990s. Reg. Sci. Urban Econ. 2014, 45, 80-89. [CrossRef]

18. Yoon, H.; Currid-Halkett, E. Industrial gentrification in West Chelsea, New York: Who survived and who did not? Empirical evidence from discrete-time survival analysis. Urban Stud. 2015, 52, 20-49. [CrossRef]

19. Crewe, L.; Beaverstock, J. Fashioning the city: Cultures of consumption in contemporary urban spaces. Geoforum 1998, 29, 287-308. [CrossRef]

20. Niedt, C. Gentrification and the grassroots: Popular support in the revanchist suburb. J. Urban Aff. 2006, 28, 99-120. [CrossRef]

21. Van den Berg, M. Femininity as a city marketing strategy: Gender bending Rotterdam. Urban Stud. 2012, 49, 153-168. [CrossRef]

22. Wright, M.W. Feminicidio, narcoviolence, and gentrification in Ciudad Juárez: The feminist fight. Environ. Plan. D 2013, 31, 830-845. [CrossRef]

23. Spain, D. Gender and urban space. Annu. Rev. Sociol. 2014, 40, 581-598. [CrossRef]

24. Gospodini, A. Portraying, classifying and understanding the emerging landscapes in the post-industrial city. In Dialogues in Urban and Regional Planning; Routledge: London, UK, 2008; pp. 34-71.

25. Zukin, S. Reconstructing the authenticity of place. Theor. Soc. 2011, 40, 161-165. [CrossRef]

26. Gant, A.C. Tourism and commercial gentrification. In Proceedings of the RC21 International Conference on “The Ideal City: Between Myth and Reality, Representations, Policies, Contradictions and Challenges for Tomorrow's Urban Life", Urbino, Italy, 28 August 2015; pp. 27-29.

27. Guerrieri, V.; Hartley, D.; Hurst, E. Endogenous gentrification and housing price dynamics. J. Public Econ. 2013, 100, 45-60. [CrossRef]

28. McKinnish, T.; Walsh, R.; White, T.K. Who gentrifies low-income neighborhoods? J. Urban Econ. 2010, 67, 180-193. [CrossRef] [PubMed]

29. Meltzer, R.; Ghorbani, P. Does gentrification increase employment opportunities in low-income neighborhoods? Reg. Sci. Urban Econ. 2017, 66, 52-73. [CrossRef]

30. Carpenter, J.; Lees, L. Gentrification in New York, London and Paris: An international comparison. Int. J. Urban Reg. 1995, 19, 286-303. [CrossRef]

31. Atkinson, R. The hidden costs of gentrification: Displacement in central London. J. Hous. Built Environ. 2000, 15, 307-326. [CrossRef]

32. Butler, T.; Lees, L. Super-gentrification in Barnsbury, London: Globalization and gentrifying global elites at the neighbourhood level. Trans. Inst. Br. Geogr. 2006, 31, 467-487. [CrossRef]

33. Pratt, A.C. Urban regeneration: From the arts 'feel good' factor to the cultural economy: A case study of Hoxton, London. Urban Stud. 2009, 46, 1041-1061. [CrossRef]

34. Hamnett, C. City centre gentrification: Loft conversions in London's city fringe. Urban Policy Res. 2009, 27, 277-287. [CrossRef]

35. Smith, N.; DeFilippis, J. The reassertion of economics: 1990s gentrification in the Lower East Side. Int. J. Urban Reg. 1999, 23, 638-653. [CrossRef]

36. Osman, S. The Invention of Brownstone Brooklyn: Gentrification and the Search for Authenticity in Postwar; Oxford University Press: New York, NY, USA, 2011.

37. Shkuda, A. The Lofts of SoHo: Gentrification, Art, and Industry in New York, 1950-1980; University of Chicago Press: Chicago, IL, USA, 2016.

38. Goldstein, B.D. The Roots of Urban Renaissance; Harvard University Press: Cambridge, MA, USA, 2017. 
39. McGurik, P.M.; Winchester, H.P.; Dunn, K.M. Entrepreneurial approaches to urban decline: The Honeysuckle redevelopment in inner Newcastle, New South Wales. Environ. Plan. A 1996, 28, 1815-1841. [CrossRef]

40. Rofe, M.W. From 'problem city' to 'promise city': Gentrification and the revitalisation of Newcastle. Aust. Geogr. Stud. 2004, 42, 193-206. [CrossRef]

41. Levine, M.A. Government policy, the local state, and gentrification: The case of Prenzlauer Berg (Berlin), Germany. J. Urban Aff. 2004, 26, 89-108. [CrossRef]

42. Ahlfeldt, G.M.; Maennig, W.; Richter, F.J. Urban renewal after the Berlin Wall: A place-based policy evaluation. J. Econ. Geog. 2016, 17, 129-156. [CrossRef]

43. Diappi, L.; Bolchi, P. Gentrification waves in the inner-city of Milan. In Innovations in Design E Decision Support Systems in Architecture and Urban Planning; Springer: Dordrecht, The Netherlands, 2006; pp. 187-201.

44. Kaika, M.; Ruggiero, L. Land financialization as a 'lived'process: The transformation of Milan's Bicocca by Pirelli. Eur. Urban Reg. Stud. 2016, 23, 3-22. [CrossRef]

45. Martí-Costa, M.; Pradel, M. The knowledge city against urban creativity? Artists' workshops and urban regeneration in Barcelona. Eur. Urban Reg. Stud. 2012, 19, 92-108. [CrossRef]

46. Gant, A.C. The invention of the Barcelona gothic quarter. J. Herit. Tour. 2014, 9, 18-34. [CrossRef]

47. Ley, D.; Dobson, C. Are there limits to gentrification? The contexts of impeded gentrification in Vancouver. Urban Stud. 2008, 45, 2471-2498.

48. Podmore, J. (Re)reading the 'loft living' habitus in Montreal's inner city. Int. J. Urban Reg. 1988, $22,283-302$. [CrossRef]

49. Lloyd, R. Neo-bohemia: Art and neighborhood redevelopment in Chicago. J. Urban Aff. 2002, 24, 517-532. [CrossRef]

50. Shaw, W.S. Sydney's SoHo Syndrome? Loft living in the urbane city. Cult. Geogr. 2006, 13, $182-206$. [CrossRef]

51. Zheng, S.; Kahn, M.E. Does government investment in local public goods spur gentrification? Evidence from Beijing. Real Estate Econ. 2013, 41, 1-28. [CrossRef]

52. Yang, Z.; Hao, P.; Cai, J. Economic clusters: A bridge between economic and spatial policies in the case of Beijing. Cities 2015, 42, 171-185. [CrossRef]

53. Garfield, E. Citation Index for Science. A New Dimension in Documentation through Association of Ideas. Science 1955, 122, 108-111. [CrossRef]

54. Salvador-Oliván, J.A.; Agustín-Lacruz, C. Correlación entre indicadores bibliométricos en revistas de Web of Science y Scopus. Rev. Gen. Inf. Doc. 2015, 25, 341-359. [CrossRef]

55. Van Eck, N.J.; Waltman, L. Software survey: VOSviewer, a computer program for bibliometric mapping. Scientometrics 2010, 84, 523-538. [CrossRef] [PubMed]

56. Rey-Martí, A.; Ribeiro-Soriano, D.; Palacios-Marqués, D. A bibliometric analysis of social entrepreneurship. J. Bus. Res. 2016, 69, 1651-1655. [CrossRef]

57. Castillo-Vergara, M.; Alvarez-Marin, A.; Placencio-Hidalgo, D. A bibliometric analysis of creativity in the field of business economics. J. Bus. Res. 2018, 85, 1-9. [CrossRef]

58. García, L.M.; Díaz, M.C. El proceso de elitización. Investigaciones y temas de análisis en la Geografía española (1999-2008). Scr. Nova 2008, 270, 26-30.

59. Rojo, F. La gentrificación en los estudios urbanos: Una exploración sobre la producción académica de las ciudades. Cadernos Metrópole 2016, 18, 697-719. [CrossRef]

60. Hirsch, J.E. An index to quantify an individual's scientific research output. Proc. Natl. Acad. Sci. USA 2005, 102, 16569-16572. [CrossRef]

61. Peck, J. Stuggling with the creative class. Int. J. Urban Reg. 2005, 29, 740-770. [CrossRef]

(C) 2018 by the authors. Licensee MDPI, Basel, Switzerland. This article is an open access article distributed under the terms and conditions of the Creative Commons Attribution (CC BY) license (http:/ / creativecommons.org/licenses/by/4.0/). 